\title{
4. 遺伝性疾患とムコ多糖*
}

谷口昂米

ムコ多糖代謝異常を primary defects とする遺伝性疾 患は, McKusick ${ }^{1}$ (Oct. 1977) により遺伝性ムコ多糖症 (MPS) I一VIII型（V型は空白）に分類され，それぞれ の欠損酵素もほぼ全貌が明らかにされてきた。しかし， 欠損酵素が判明したとはいらものの, 酵素基質には入手 困難なものも多く, 依然として確定診断の浻路になって いる. 酵素診断の困難な病型は勿論のこと, 酵素診断の 前段階としても，尿中ムコ多糖の性状などから病型を推 定するいわゆる“Tentative Diagnosis”を要することも 多い，ここでは，正常人，遺伝性ムコ多糖症 I一III型の 尿中ムコ多糖の排泄パターン，性状を中心とした病型分 類とその限界について述べるとともに, 臨床像は遺伝性 ムコ多糖症に酷似し, 細胞レベルでのムコ多糖代謝に異 常が推定されながら，尿中ムコ多糖に異常のみられない 疾患の 1 つであるI-cell 病について, 末梢血りンパ球を 利用する診断へのアプローチについてふれてみたい．

\section{1. 血漿ムコ多糖2}

血漿ムコ多糖はトリクロール酶酸（TCA）で沈殿する 蛋白分画に主に含まれ，TCA 上清には見出されない。 TCA 沈殿物をェーテルで洗浄, TCA を除き, プロナー セ消化，エタノール沈殿， CPC 沈殿を行ってムコ多糖 粗分画を得た．正常人血漿 $100 \mathrm{ml}$ あたり $168 \sim 272 \mu \mathrm{g}$ (ウロン酸) 前後の収量である. このよらにして得られ た血漿ムコ多糖は電気泳動, 酵素分解, 2 糖マッピング の成績からみて, undersulfated の chondroitin 4 硫酸 を主とし，量的には少ないが通常の chondroitin 4 硫酸 も見出される. 主成分である undersulfated chondroitin 4 硫酸は, 構成 2 糖として $\Delta \mathrm{Di}-4 \mathrm{~S}$ と $\Delta \mathrm{Di}-0 \mathrm{~S}$ を添潘 等モルに含む. 時に, 微量の chondroitin 6 硫酸と思わ れる分画が検出されたが, hyaluron 酸, heparan 硫酸 に相当する分画は見出されなかった，検索し得た 1 例の MPS II 型の血漿ムコ多糖は, 正常者との間に差は見出

\section{し得なかった。}

\section{2. 尿中ムコ多糖の電気泳動像 ${ }^{3)}$}

$\mathrm{CPC}$ 沈股法により得られた尿中ムコ多糖の酢酸バリ ウム中での電気泳動像は, 血漿ムコ多糖ほど単純ではな い. 正常尿では chondroitin 4/6 硫酸を主成分とし, dermatan 硫酸, heparan 硫酸に一致する分画が見出さ れる. Heparan 硫酸に一致する分画は，年龄とともに排 泄比率が高くなる傾向にある. 遗伝性ムコ多糖症の尿中 ムコ多糖の泳動像は，MPS I， II，且型にそれぞれ特 徵的であり, 正常尿とも明らかに異なって㧍り，一見し て病型の推定も可能である (Fig. 1).

従来, MPS I 型の尿には dermatan 硫酸>heparan

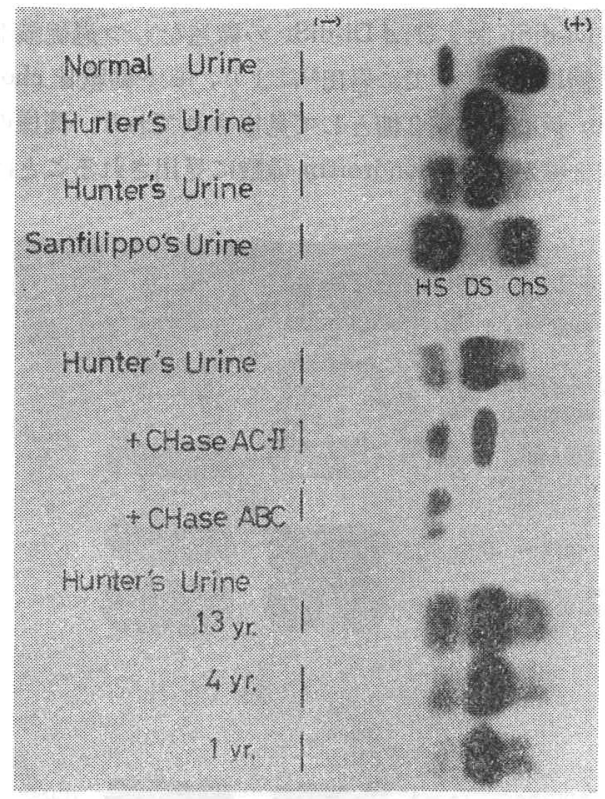

Fig. 1. 尿中ムコ多糖の電気泳動像. ( $0.05 \mathrm{M}$ 酢酸バリウム).

* Some heritable disorders with abnormal mucopolysaccharide metatolism.

** Noboru Taniguchi, 金沢大学医学部小児科学教室. 
硫酸，MPS II 型では dermatan 硫酸 $\doteqdot$ heparan 硫酸の 比率で排泄されるとされ，この比率が鑑別上も重要視さ れてきた。確かにある程度以上の年齢であれば問題はな いが，Fig. 1 からも明らかなように乳児期には MPS II 型であっても heparan 硫酸の排泄比率の低い例もあり, 泳動パターンのみからの判定に困難を感ずることがあ る。

\section{3. 尿中コンドロイチン硫酸異性体の 2 糖マッピン グ法による検討4)}

正常糖ムコ多糖の chondroitinase AC 分解物には, 既知の不飽和 2 桾である $\Delta \mathrm{Di}-0 \mathrm{~S}, \Delta \mathrm{Di}-4 \mathrm{~S}, \Delta \mathrm{Di}-6 \mathrm{~S}$ の湾か、, より易動度の遅い紫外線吸収スポットが見出 される (Fig. 2).

Fraction 1 は chondroitinase $\mathrm{ABC}$ により $\triangle \mathrm{Di}-6 \mathrm{~S}$ と $\triangle \mathrm{Di}-4 \mathrm{~S}$ を㴽淩 1:3のモル比で与えることから， 恐らくは hibrid オリゴ糖と考学られる.

Fraction 2 は chondroitinase に対する態度から $\Delta$ DidiSD と推定されたが, 微量成分のため 確定し得なかっ た.

Fraction 3 chondro-4-sulfatase, chondro-6-sulfatase により $\triangle \mathrm{Di}$-OS を与光るので $\Delta \mathrm{Di}$-diSE と考兄ら 机る。

$\triangle \mathrm{Di}$-diSD 抢よび $\Delta \mathrm{Di}$-diSE の構造をもつ過硫酸不飽 和 2 糖単位は, すでに岩田 ${ }^{5}$ により, ヒト助軟骨 chondroitin 硫酸の構成 2 糖として見出されて拈り, 同様の過 硫酸 2 糖が尿中 chondroitin 硫酸に見出されることは興

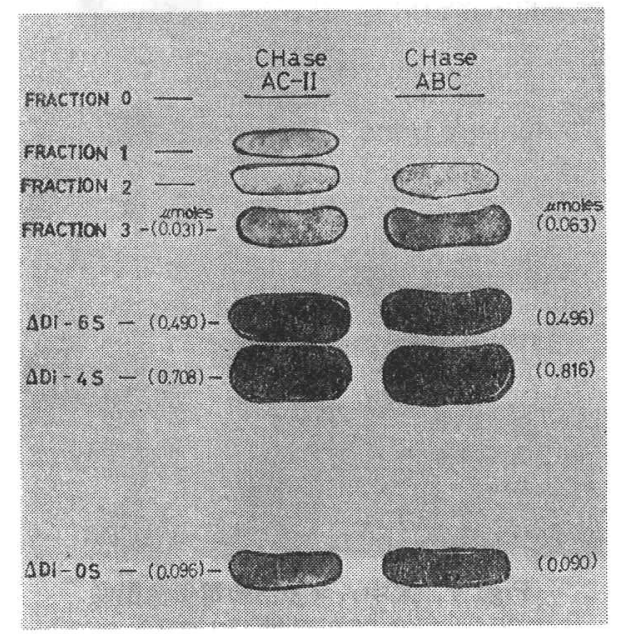

Fig. 2. 尿中ムコ多糖 (正常尿) のコンドロイチ ナーゼ分解物の 2 糖マッピング.

（）：尿中么コ多糖 $1 \mathrm{mg}$ 当りの不飽和 2 糖量.
味深い. Fraction 1 のような hybrid 構造をむつオリゴ 糖は, ヒト半月板の chondroitinase AC 分解物中にさま ざまな鎖長をもつものが見出され， dermatan 硫酸鎖の 不均一性を物語るものとされている.6)

Fraction 0 (chondroitinase AC 抵抗性分画) は, chondroitinase $\mathrm{ABC}$ により $\triangle \mathrm{Di}$-4 S および $\Delta \mathrm{Di}$-diS と思われる 2 糖を約 4:1のモル比で生じた.この過硫 酸 2 糖は chondrosulfatase に対する態度から $\Delta \mathrm{Di}$-diSs と考光られた。

以上のことから, 正常者では尿中 chondroitin $4 / 6$ 硫 酸鎖から得られる主な過硫酸 2 糖は $\Delta \mathrm{Di}$-diSE であり, dermatan 硫酸鎖から得られるものは $\Delta \mathrm{Di}$-diSs と考完 られる。この上らな過硫酸 2 桾は, 遺伝性ムコ多糖症の chondroitin 硫酸異性体にも見出され，全 2 糖単位に対 する比率を比較してみても, 正常者と遗伝性ムコ多糖症 の間に差は見出し得ない。

\section{4. 尿中ヘパラン硫酸の性状》}

尿中ムコ多糖の chondroitinase $\mathrm{ABC}$ 抵抗性分画は， その分析值からみて主に heparan 硫酸からなると考光 られる。この分画は酰酸バリウム中の電気泳動では, heparan 硫酸標品に一致する単一なバンドとして泳動さ れるが, $0.1 \mathrm{M} \mathrm{HCl}$ 中では, heparan 硫酸に湾涪一致 する分画と heparin に近い易動度をもつ分画に分れる (Fig. 3).すなわら, 正常人, 遺伝性ムコ多糖症の尿中 heparan 硫酸は, いずれも硫酸基含量を異にする 2 分画

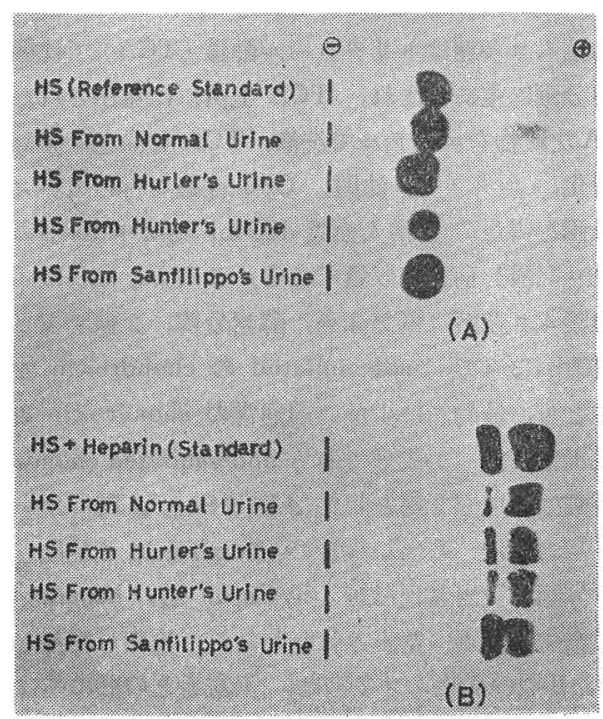

Fig. 3. 尿中へパラン硫酸の電気泳動像. $\mathrm{A}: 0.05 \mathrm{M}$ 酶酸バリウム, B $: 0.1 \mathrm{~m} \mathrm{HCl}$. 


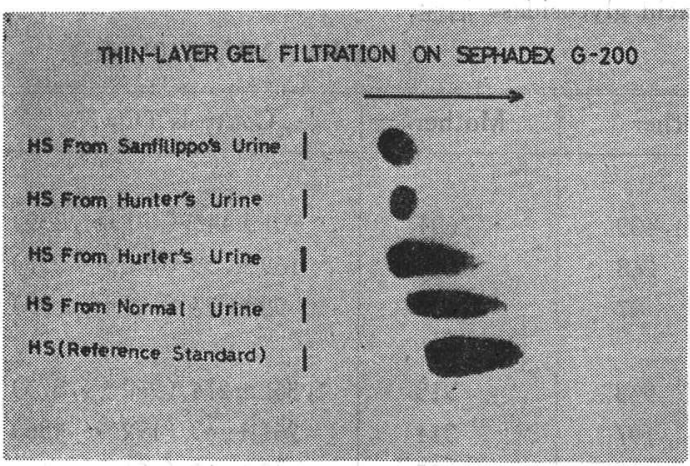

Fig. 4. 尿中へパラン硫酸の薄層ゲル汇過クロ マトグラム。

からなることが判る.

上述のように, 電気泳動では正常人と遗伝性ムコ多糖 症の尿中 heparan 硫酸には質的な相違は見出し得ない が，薄層げル沪過法で分子サイズを比較してみると明ら かな差がみられる (Fig. 4). MPS III 型と II 型の尿中 heparan 硫酸は分子サイズも小で，まとまったスポット として移動するのに対し, 正常尿の heparan 硫酸は, 幅広いバンドとなり,その分子サイズも大きい. MPS I 型の heparan 硫酸は, MPS II 型のそれにほぼ一致する 分画と正常尿のそれに近い分画の混合物と考光られた。

\section{5. 尿中ムコ多糖の排泄比率 ${ }^{32}$}

それぞれの尿中ムコ多糖の構成 2 糖, 電気泳動像など
には正常人と遺伝性ムコ多糖症の間に殆んぞ差はみられ ないので, 病型類別にあたっては, それぞれのムコ多糖 の排泄比率が最も重要と考光られ， chondroitin 4/6 硫 酸, dermatan 硫酸, heparan 硫酸の分別定量が必要に なる。

尿中ムコ多糖の chondroitinase AC 分解物を展開後 は, 原点に dermatan 硫酸+ heparan 硫酸が, chondroitinase ABC 分解物の場合には heparan 硫酸が残ると考 えられるので, 同量の未分解ムコ多糖を同様に処理し, これらのウロン酸量を測定することによって，それぞれ のムコ多糖量を算出することが出来る. 個々のムコ多糖 のウロン酸測定時の発色率の差を考慮すれば, 電気泳動 により求めた值とよく一致する (Table 1). しかし, そ の簡便性からみてもセルロースアセテート膜による電気 泳動法が，尿中ムコ多糖の排泄比率の大要を知るには最 も適して拉り，病型類別への第 1 歩と考光られるが，こ のよらな方法で確かめられる病型の種類は限られて沶 りなたあくまでも tentative diagnosis にすぎない ので，容易に利用出来る酵素基質の開発がまたれる.

\section{I-cell 病リンパ球のリソソーム酵素}

MPS I 型に酷似した臨床像を示す I-cell 病では，培 養線維芽細胞を用いると遺伝性ムコ多糖症に近い ${ }^{25} \mathrm{~S}$ の とりこみがみられるが, ${ }^{8}$ 肝などの臟器にはムコ多糖の増 加は証明されていないし, 尿中へのムコ多糖排泄の増加 もない.9) 本症の培養線維芽細胞では $\beta$-ガラクトシダー

Table 1. 尿中ムコ多糖の排泄比率 (\%).

\begin{tabular}{l|c|c|c|c|c|c}
\hline \hline & \multicolumn{3}{|c|}{$\begin{array}{c}\text { Electrophoresis } \\
\text { (Densitometric value) }\end{array}$} & \multicolumn{3}{|c}{$\begin{array}{c}\text { Enzymatic method } \\
\text { (Bitter-Muir carbazole value) }\end{array}$} \\
\cline { 2 - 7 } & ChS A/C & DS & HS & ChS A/C & DS & HS \\
\hline Normal & & & & & & \\
1. 3 yr. M. (6.8 mg/day) & 94.0 & trace & 6.0 & 90.1 & 0 & 9.9 \\
2. 8 yr. F. (8.4 mg/day) & 81.3 & 8.2 & $10.5(9.0) *$ & 77.2 & 4.2 & 18.6 \\
3. pooled (7.2 mg/l) & 82.0 & 6.0 & $12.0(12.1)$ & 74.5 & 3.9 & 21.6 \\
MPS-I & & & & & & \\
4 yr. M. (122.4 mg/day) & 8.2 & 82.0 & $9.8(10.5)$ & 12.3 & 69.2 & 18.5 \\
MPS-II & & & & & & \\
1. 1 yr. M. (16.0 mg/dl) & 22.9 & 64.0 & 13.1 & 28.8 & 49.0 & 22.2 \\
2. 4 yr. M. (106.0 mg/day) & 16.8 & 61.9 & $21.3(20.5)$ & 23.2 & 42.8 & 34.0 \\
3. 13 yr. M. (98.6 mg/day) & 13.0 & 60.0 & $27.0(29.1)$ & 15.6 & 43.6 & 40.8 \\
MPS-III & & & & & & \\
1. 2 yr. M. (62.9 mg/day) & 33.0 & 2.0 & $65.0(70.8)$ & 21.7 & 1.0 & 77.3 \\
2. 5 yr. M. (33.9 mg/day) & 41.2 & 5.7 & $53.1(56.6)$ & 26.6 & 4.0 & 69.4 \\
\hline
\end{tabular}

* 全 hexosamine に対する glucosamine のモル比 
Table 2. I-cell 病白血球の acid glycosidase 活性.

(n moles $4 \mathrm{MU} / \mathrm{h} / 10^{7}$ cells).

\begin{tabular}{l|r|r|r|r}
\hline \hline & Patient & Father & Mother & Controls (n=8) \\
\hline PMN & & & & \\
$\beta$-Glucosaminidase & 1,174 & 1,409 & 604 & $901 \pm 445(407 \sim 1,839)$ \\
$\beta$-Galactosidase & 133 & 268 & 117 & $169 \pm 53(106 \sim 277)$ \\
$\beta$-Glucuronidase & 50 & 97 & 36 & $52 \pm 17(39 \sim 95)$ \\
LYMPH (Before culture) & & & & \\
$\beta$-Glucosaminidase & $517(38 \%)$ & 933 & 913 & $1,362 \pm 274(960 \sim 1,873)$ \\
$\beta$-Galactosidase & $37(14 \%)$ & 197 & 314 & $2611+43(192 \sim 486)$ \\
$\beta$-Glucuronidase & $13(30 \%)$ & 32 & 35 & $43 \pm 12(31 \sim 66)$ \\
LYMPH (Cultured for $72 \mathrm{~h})$ & & & & \\
$\beta$-Glucosaminidase & $288(32 \%)$ & 1,109 & 838 & $904 \pm 269(540 \sim 1,181)$ \\
$\beta$-Galactosidase & $16(9 \%)$ & 198 & 108 & $170 \pm 63(92 \sim 246)$ \\
$\beta$-Glucuronidase & $11(29 \%)$ & 39 & 29 & $37 \pm 14(25 \sim 58)$ \\
\hline
\end{tabular}

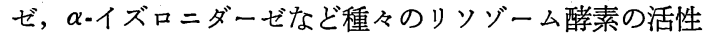
低下が証明されるが，末梢白血球のリソゾーム酵素には 活性の低下はないとされている. ${ }^{10)}$ しかし，本症の末梢 血リンパ球には著名な空泡化が観察され，これは糖蛋 白ムコ多糖の異常蓄積のため膨大したリソゾームその ものとされていることからも，リンパ球ではこれらの分 解に関与するリソゾーム醳素の活性低下が予想される. 末梢白血球は主に好中球, リンハ球よりなるが，これら はその機能, life cycle の点からみても全く異質な細胞 群であり, 当然, それぞれの細胞に㧊けるリソゾーム酵 素の活性表現には差のあることが考えられる. I-cell 病 の培養線維芽細胞では, 種々のリソゾーム酵素の活性低 下が証明されるが，肝，脳などでは， $\beta$-ガラクトシダー ゼの活性低下のみがみられ，他の酵素活性は正常に保た れることからも,9細胞の種類による活性表現の差は無視 出来ない，好中球とリンパ球についてみると，好中球で は I-cell 病と正常者の間に差はみられないが，リンパ球 では $\beta$-ガラクトシダーゼをはじめ種々の酵素の活性低下 がみられ，PHA 刺㦸培㽰によりその差はより明らが なる (Table 2). しかし, 両親と正常者の間には差はみ られない。

一般にリソゾーム蓄積症の診断は, 培養線維芽細胞に ついて欠損酵素を証明するのが信頼性の高い標準的な方 法とされ，末梢白血球でも酵素欠損の証明されることが
多い。しかし, 糖原病II型のように培養線維芽細胞やリ ソパ球では酵素欠損が証明されるが，好中球では証明出 来ない疾患もあり,リンパ球のリソゾーム酵素の活性表 現には, 培養線維芽細胞と相通ずるものがあるとも考兄 られるので，採取，取扱いの簡便さからみて，末梢りン パ球は, このような疾患の診断により広く用い得るよう である。

\section{文献}

1) McKusick, V. A. : Am. J. Hum. Genet., 30 : 105, 1978.

2) Taniguchi, N. et al. : Clin. Chim. Acta, 50 : 319, 1974.

3) Taniguchi, N. et al. : Biochem. Med., 14 : $241,1975$.

4) Taniguchi, N. et al. : Biochem. Med., 15 : 169, 1976.

5) 岩田 久：日整会誌, $43: 455,1969$.

6) Habuchi, H. et al. : J. Biol. Chem., 248 : 6019, 1973.

7) Taniguchi, N. et al. : Clin. Chim. Acta, 60 : 363, 1975.

8 ) Schmickel, R. D. et al. : J. Lab. Clin. Med., $86: 672,1975$.

9) Leroy, J. G. et al. : Pediatr. Res., $6: 752$, 1972.

10) Wiesmann, U. N. et al. : Acta Paediat. S.cand., $63: 9,1974$. 